Kafkas Üniversitesi Sosyal Bilimler Enstitüsü Dergisi

Kafkas University Journal of the Institute of Social Sciences

Bahar Spring 2020, Sayı Number 25, 241-263

DOI:10.9775/kausbed.2020.015

Gönderim Tarihi: 28.02.2020

Kabul Tarihi: 15.04.2020

SURIYELI MÜLTECILERIN UYUM SÜRECINDE ISSCCI
ÖRGÜTLERININ AKTÖRLEŞ(EME)ME DENEYIMLERI:
FENOMONOLOJIK YÖNTEMBILIMSEL BIR İNCELEME

\title{
Workers' Organizations' Experience of Being Actors or not in the Integration Process of Syrian Refugees: A Phenomenological Research
}

\author{
Fethiye TILBE \\ Arş. Gör. Dr., Tekirdağ Namık Kemal Üniversitesi \\ ftilbe@nku.edu.tr \\ https://orcid.org/ \\ ORCID ID: 0000-0002-3188-9477 \\ Çalışmanın Türü: Araştırma
}

\begin{abstract}
$\ddot{\mathrm{O} z}$
Göç sonuçları kolaylıkla tahmin edilemeyen bir olgu olmakla birlikte hem göç veren hem de göç alan toplumlar üzerinde dönüşürücü bir etkiye sahip olabilmektedir. Söz konusu dönüşürücü etki hem sosyal ve kültürel hem de ekonomik alanda kendini gösterebilir. Bu etkinin olumlu seyir izleyebilmesinde göç alan ülkelerdeki uyum politikalarının önemi büyüktür. Uyum politikalarının oluşumunda ise çok yönlü diyalog mekanizmasının kurulması, politikaların etkinliğini kuşkusuz arttıracaktır. Bu kapsamda çalı̧̧mada, diyalog mekanizmasının bir tarafi olması beklenen işçi örgütlerinin Suriyeli göçmen işçilerin işgücü piyasasına uyumlarına doğrudan, genel uyumlarına ise dolaylı katkl sağlayarak aktörleș(eme)me deneyimleri, yöntembilimsel olarak fenomonolojik yaklaşım çerçevesinde incelenecektir. Bu amaçla gerçekleştirilecek veri analizinde, politika yapım süreçlerine katkı sağlayabilecek konfederasyon düzeyindeki işçi örgütleri ile gerçekleştirilen görüşmelerden yararlanilacaktır.

Anahtar Kelimeler: Göç, Suriyeli mülteciler, uyum, işgücü piyasası, işçi örgütleri.

Abstract

Although migration results are not easily predictable, they can have a transformative effect on both sending and receiving societies. This transformative effect can occur in both social and cultural and economic spheres. Integration policies in receiving countries are extremely important for this effect to be positive. Establishing a multi-stakeholder dialogue mechanism in the formation of integration policies will undoubtedly increase the effectiveness of the policies. In this context, the role of workers' organizations, which are expected to be a part of the dialogue mechanism, by directly contributing to the adaptation of the Syrian migrant workers to the labor market, and indirectly to their overall harmony, will be examined methodologically within the framework of the phenomenological approach. In the data analysis to be carried out for this purpose, interviews with workers'
\end{abstract}

$1 \mathrm{Bu}$ çalışmanın taslağı ilk olarak, yazar tarafindan danışmanlığı yürütülen “Akad'emek 2019 Söz Çalışma Ekonomisi Öğrencilerinde” öğrenci kurultayı için hazırlanan metin ile ortaya çıkmıştır. Çalışma kapsamında yapılan görüş̧meler öğrenciler eşliğinde yazar tarafindan gerçekleştirilmiş̧ir. Daha sonra oluşturulan bildiri metni "The Migration Conference 2019 Bari”de sunulmuş ancak tam metin olarak basılmamıştır. Makale kurgusu ve yazımı tümüyle yazara aittir. 
organizations at the confederation level, which can contribute to policy making processes, will be used.

Keywords: Migration, Syrian refugee, integration, labor market, workers' organizations.

\section{GíRiş}

Türkiye 1990'lı yıllardan itibaren farklı ülkelerden düzensiz emek göçlerine tanık olmuştur. Sayıları karşılaştırılabilecek nicelikte olmasa da işgücü piyasasına yansıması bugün ki mülteci akımlarıyla benzer nitelikte olmuştur. Mülteci ya da daha genel olarak düzensiz göçmen akımları sermayeye ucuz işgücü avantajı sağlayarak tercih edilirken, kayıtdışı istihdamın belirleyicisi ve ücretin baskılayıcı unsuru olarak yerel işgücü tarafından işgücü piyasasının "istenmeyenleri" olarak damgalanmıştır. Medyanın da yeniden ürettiği bu söylem, göçmenler perspektifinden istenmeyenler algısını pekiştirerek daha da kötü koşulları kabullenme dışında bir alternatif bırakmamaktadır. Ancak bu kabullenme ve zorunlu rıza gösterme hali, yerel işgücü cephesinde var olan tepkileri daha da derinleştirmekte ve yaratılan bu kısır döngü sermaye lehine ucuz işgücünün sürekliliğini ve katlanan avantajını beraberinde getirmektedir. Özellikle Suriyeli göçmenler özelinde uyum sürecinin fazlasıyla tartışıldığı bu günlerde, uyum sorununun odağını salt dil ve kültürel farklılıklar temelinde kurgulamak asıl sorunları görünmez kılabilir. Temel gereksinimlerini karşılayabilmek için yeterli bir gelir elde edemeyen bireyin hele ki yabancısı olduğu bir toplum ile olumlu ilişkiler kurmasını beklemek bir yanılsamadır. Kaldı ki uyum, tarafların, ağırlıklı olarak olumlu etkileşimleri sonucunda şekillenen bir süreci ifade eder. Dolayısıyla bir yandan göçmen emeğinin değeri ölçüsünde ücret almasını ve örgütlenmesini, öte yandan yerel işgünün, ücreti baskılayan unsur olarak gördüğü göçmen emeğine yönelik tepkisini en aza indirmeyi sağlayacak önlemlerin tartışılması büyük önem arz etmektedir. İşgücü piyasasının düzenleyici ya da müdahaleci aktörleri olan iş̧̧i örgütlerinin bu konudaki etkinliğinin önemi yadsınamaz. Bu noktada işçi sendikalarının sorumluluk alanlarıyla geçici koruma altındaki Suriyelilerin sorunlarının kesiştiği nokta. temel olarak dört açıdan incelenebilir: Birincisi, "düşük ücretlerle ve çok kötü çalışma koşulları altında kayıt dışı olarak istihdam edilen Suriyelilerin, işgücü piyasalarında dibe doğru yarış nedeniyle yerel işgücünün istihdamı, ücretleri ve çalışma koşulları üzerinde olumsuz etkileri” (Erdoğdu, 2018, s.33); ikincisi, işçi örgütlerinden beklenen ve tanımlı sorumluluk alanları doğrultusunda kayıtdışı istihdam karşısında ilkesel mücadeleci tutum nedeniyle salt yerel işgücü üzerindeki kazanılmış hakların baskılanması perspektifinden değil, sermayeyle mücadelede yerliyabancı ayrımı yapmaksızın "emek" merkezli bakış açısının bir sonucu 
olması; üçüncüsü, "örgütlü oldukları sektörlerde Suriyeli işçilerin kendi üyeleriyle rekabete sokulması nedeniyle toplu sözleşme müzakerelerinin olumsuz etkilenmesi ve sendikasızlaşmanın artması" (Erdoğdu, 2018, s.33); dördüncüsü de, Suriyeliler perspektifinden bir bakış gibi görünen ancak tüm diğer gerekçeleri de içeren, temel geçimi uyum sürecinin merkezinde gören yaklaşımın bir uzantısı olarak işçi örgütlerini uyum sürecinin doğrudan aktörleri olarak tanımlayan bakış açısının getirdiği yükümlükler. Çalışma kapsamında, dördüncü gerekçe üzerinden, üst düzey işçi örgütlerinin (konfederasyonların) aktörleşme/aktörleşememe deneyimleri fenomonolojik yöntembilimsel yaklaşım aracılığıyla "uyum/entegrasyon" ve "çatışma" kavramları çerçevesinde incelenecektir.

\section{YÖNTEM}

Pozitivizmin aksine sayılardan ziyade, alg1 ve bilinci yansitan sözcüklerle gerçekliği araştıran fenomenologlar, deneyim odaklı hareket ederek birçok bireyin belli bir kavram ya da fenomen ile ilgili yaşanmış deneyimlerinin ne anlama geldiğini tanımlamaya çalışırlar (Creswell, 2007; Finlay, 2009). Araştırmacı bu amacı gerçekleştirmek için, neden-sonuç ilişkilerine dayalı bütün açıklamaları bir kenara bırakarak, deneyimler veya fenomenlerin temelinde yatan gerçek mantığı ortaya çıkarmaya çalışır (Dukes, 1984; Güler, Halıcıoğlu \& Taşğın, 2013, s.234). Bu yaklaşımın öncüsü olan Husserl'ın asıl amac1, duygu ya da algı gibi öznel konuların bilimsel incelemesini, nesnel olarak yürütebilmek için bir çözüm üretmektir. Kockelmans'1n belirttiği gibi (1973, s.274); o dünyaya yönelik somut yönelim amaçlarını güdüleyen, genellikle saklı olan anlamları aydınlatmayı dener. Fenomenolojik yaklaşımı kullananlar, deneyimlere yön veren önemsenmeyen varsayımları ortaya çıkarmaya çalışır (Hein \& Austin, 2001, s.6). Gerçekte, hiçbir nesnel gerçeklik yoktur, daha ziyade kişilerin gerçekliği olan deneyimleri ve onları algılamaları söz konusudur. Bilinci ve algıyı yansıtan öz ise, bir sonraki davranış olasılıklarını da değerlendirmeyi olanaklı kılar. Dolayısıyla işçi örgütlerinin, Suriyeli mültecilerin uyum sürecindeki rollerini, göç ve göçmen emeğine yönelik deneyimleri ve dolayısıyla algı düzeylerini içerecek şekilde bakışları üzerinden inceleme isteği, çalışmada fenomenolojik yaklaşımın seçilmesinin temel gerekçesini oluşturmaktadır. $\mathrm{Bu}$ gerekçelerle çalışmada, politika yapım sürecinde etkinlik olasıllı̆̆ının yüksek olduğu düşünülen üst düzey işçi örgütleri olan Disk, Türk-İş ve Hak-İş ile görüşmeler gerçekleştirilmiştir. Elde edilen veriler ise, fenomonolojik araştırmanın analizine uygun olarak üç aşamalı kodlama yürütülerek analiz edilmiştir. $\mathrm{Bu}$ çerçevede neyin, nasıl deneyimlendiği bütünsel bir bakışla sunulup, bireylerin elde ettikleri 
deneyimlerin öz'ü tartışılmış, inceleme nesnesi olan fenomenin bir betimlemesi yapılarak, fenomenolojik çalışmanın son noktası olan öz'e ulaşılmıştır.

\section{KURAMSAL TARTIŞMA: ÇATIŞMA VE UYUM}

Uyum sözcüğünü göç kapsamında kavramsal ve olgusal olarak tartışırken genellikle kültür(süz)leşme, çokkültürlülük/ çokkültürcülük, kaynaşma, adaptasyon (uyum), asimilasyon ya da entegrasyon (bütünleşme) kavramlarıyla karşılaşırız. Unutulmaz (2012, s.139), tüm kavramların kullanıldıkları bağlama son derece bağımlı olarak ve kendilerini kullanan kişinin amaç ve görüşlerine göre politik anlamlar kazandığını ifade eder. Kavramların tercihi, siyasal ve sosyolojik bir takım nedenlerin yansıması olmakla birlikte, ülkelerin siyasi tercihlerinin bir sonucu olarak değişim ve dönüşüm gösterebilir. Ancak Türkçe'de uyum ya da bütünleşme anlamında kullanılan entegrasyon kavramı, İngilizce ve Fransızca başta olmak üzere pek çok dilde baskın ve evrensel bir kullanıma sahiptir.

Kuşaklar boyu devam eden bir süreç olarak entegrasyon, yüksek göçmen sayılarının olduğu günümüz toplumlarının güncel, bir o kadar da tartışmalı konularından biridir. Entegrasyon kavramı dilsel, kültürel, eğitim süreçleri, işgücü piyasası gibi özgün ve toplumsal alanların her biri için kullanılabilmektedir (Kartal, 2018, s.119). Entegrasyon, toplumsal yaşamın işgücü piyasası, eğitim ve öğretim süreçleri gibi sağlık ve hukuk sistemi vb. temel alanlarına olabildiğince yüksek katılımı ifade etmektedir. Kartal (s.125), yaşamı bağımsız idame ettirme ve sosyal kabulün temelini oluşturan işgücü piyasasına dahil olma durumunun sürecin olumlu seyretmesinde merkezi öneme sahip olduğunu, Hartmut Esser'in entegrasyon kuramına gönderme yaparak şu ifadelerle vurgulamaktadır;

Sistem entegrasyonu ve sosyal entegrasyon ayrimina dayalı bu kuramda kimlik, kültürleşme, etkileşim ve sosyal-ekonomik-politik konum sosyal entegrasyonun temel boyutlart olarak görülür. Bu dört farklı boyut birbiriyle nedensel bir ilişki içinde olduğundan sürecin başarısı da dizgiye bağlıdır. Örneğin göçmenlerin eğitim sisteminde ve iş piyasasında yer alabilmeleri için belirli düzeyde dil yeterliliğine sahip olmalar gereklidir. Güvenli bir sosyoekonomik statüye sahip olmak ise göç alan ülkenin üyeleri ile bilgi değiş tokuşunu ve etkileşimi gerektirir. Etkileşim gerçekleştiğinde ise göç alan ülkeyle duygusal bağ oluşur. Bu yaklaşımda en çok öne çıkan, kültürel ve yapısal entegrasyon boyutudur. Yapısal faktörlerin daha çok vurgulandığı 
söylenebilir, zira toplumsal yaşamın diğer alanlarına dahil olabilmek için temel koşul, iş piyasasında güvenli bir istihdamdır.

Esser'in Entegrasyon Kuram1, entegrasyon olgusunu temel alan çalışmalarda en çok referans gösterilen kuramlardan birisidir. Esser (2000, ss. 56-66), entegrasyon kuramını, "sistem entegrasyonu" ile "sosyal entegrasyon" olarak biçimlendirmiştir.

Buna göre sistem entegrasyonu, topluma yeni katılan üyelerin, göçmenlerin bir işte çalışarak ekonomiye katkıda bulundukları, vergilerini ödedikleri ve yasalara uygun davrandıkları sürece sisteme entegre olduklarını varsayar. Sosyal entegrasyon ise sistem entegrasyonundan farklı olarak, göçmenleri sadece ekonomi kurumu ya da yasal sorumlulukları açısından değil, diğer alanlara da entegre olmalarını kapsayacak şekilde ele almaktadır (Aktaran Şahin, 2010, ss.106-107). Elbette ki göçmenlerin uyum düzeylerinin analizi, pek çok boyutun ayrı ayrı ele alınıp incelenmesiyle mümkün olabilir. Ancak çalışma, Suriyeli göçmenlerin ekonomik uyumlarını, diğer bir deyişle işgücü piyasasındaki konumlanmalarını temel alarak işçi örgütlerinin uyum sürecindeki rollerine odaklanmaktadır.

Mülteci, sığınmacı ya da düzensiz göçmen gibi hassas grupların uyum süreçlerinin, dezavantajlı konumları dolayısıyla ve pek çok faktörün etkisiyle olumlu bir seyir izleyemediğini kolaylıkla ifade edebiliriz. Var olma ve tanınma mücadelelerinin yanında, işgücü piyasasının bir katmanında sıkıştırılmış olmaları aidiyet oluşum süreçlerinin önündeki en büyük engellerdendir. İşgücü piyasasında gerekli değeri bulamama halinin, özellikle gençler, kadınlar, göçmenler ve azınlıklar arasında daha yaygın olduğu bilinen bir gerçektir (Khattab vd. 2011, Tijdens ve van Klaveren, 2011). Göçmenlik statüsünün belirsiz oluşu ise bu durumun şiddetini katlayarak arttırmakla birlikte, işgücü piyasasına girişin önünde de büyük bir engel yaratmaktadır. Göçün bir insani güvenlik arayışı olduğunu kuramsal bir model çerçevesinde açılayan Sirkeci ve Cohen (2016), bireylerin göreli çatışma algılarının, göç sonrası süreçteki deneyimlerini de şekillendirdiğini ifade ederler. Dolayısıyla göç sonrası uyum süreçlerinin incelenmesinde de açıklayıcı bir çerçeve ortaya koymaktadır. Cohen ve Sirkeci'ye göre (2011, s. 107) güvensizlik, eğitim ve sağlik sisteminin yetersizliği, siyasi bask1 ve asimilasyon çabaları, işsizlik ve etnik ayrımcılık gibi pek çok farklı ya da birbirine bağlı bileşenin etkisiyle ortaya çıkabilir. Güvensizlik, somut olduğu kadar soyut olgu ve olaylardan da kaynaklanabilmektedir (Sirkeci, 2012, s. 256). Bu insani güvensizlik algısı ise göçün farklı aşamalarında boyut değiştirerek şiddetlenebilir ya da azalabilir. Bu durum da bir kez daha göç etmeye veya geri göç etmeye yol açabilir (s.360). Ancak özellikle Suriyeli 
mülteciler gibi yüksek boyuttaki kitlesel göçler dünya ülkelerini alarma geçirdiğinden, uygulanan katı politikalar ve yüksek sınır duvarlarıyla mültecilerin hareket alanını daraltmakta ve ikinci bir göç hareketini her zaman olanaklı kılmamaktadır. $\mathrm{Bu}$ da göçmenleri ikinci kez güvensizlik algısı içinde yaşamaya mahkum kılmaktadır. Göç ve Çatışma Modeli’nin önermeleri doğrultusunda olguyu incelediğimizde, hassas göçmen gruplarının güvensizlik algılarının ve çatışma düzeylerinin göç sonrası süreçte de düzenli göçmenlere kıyasla daha yüksek olduğunu ifade edebiliriz. Uyum süreci tüm gruplar için zor iken çatışma algısı daha yüksek olan, zorunlu olarak yerlerinden ayrılan mülteciler gibi gruplar için çok daha zor olması beklenen bir durumdur.

\section{MÜLTECİ EKONOMISİ, HUKUKSAL ALTYAPI VE İŞÇİ ÖRGÜTLERİ}

Göçün değişik biçimleri üzerinden bireylerin hukuki statülerini tanımlamada, hem uluslararası hem de ulusal düzeydeki düzenlemeler belirleyicidir. Mülteci ve sığınmacı statüsündeki göçmenler için uluslararası temel belirleyici düzenleme 1951 tarihinde Cenevre'de imzalanan Birleşmiş Milletler Cenevre Sözleşmesi olarak da bilinen Mültecilerin Hukuki Durumu Hakkında Sözleşme ile 1967 y1lında New York'ta kabul edilen Mültecilerin Hukuki Statüsüne Dair Protokol'dür. Türkiye her iki düzenlemeyi de coğrafi sınırlaması ilkesiyle onaylamış, bu kapsamda Avrupa'dan gelen mültecileri kabul etmiştir. Bunlar dışında benzer statüde gelenler ise ancak 1994 tarihinde kabul edilen Yönetmelik ile uluslararası koruma kapsamına alınmıştır (Resmi Gazete sayı: 22127, 30 Kasım 1994).

2011 yılında Suriye'de başlayan krizin hemen akabinde Türkiye'ye yönelik gerçekleşen kitlesel akınlar yeni düzenlemeleri beraberinde getirmiştir. $\mathrm{Bu}$ kapsamda 4 Nisan 2013'te 6458 say1lı Yabancllar ve Uluslararası Koruma Kanunu (YUKK) yürürlüğe girmiştir. Kanun Suriyeli sığınmacıların statüsünü şartlı mültecilik olarak belirlemiştir. Hemen ardından 2014 yılında çıkarılan Geçici Koruma Yönetmeliği ile Suriyelilere sağlanan barınma, sağlık, eğitim, işgücü piyasasına erişim gibi hakların çerçevesi belirlenmiştir.

Mülteci ekonomisi kavramını kullanan Betts ve diğerlerine (2014) göre, mülteciler sahip oldukları sosyoekonomik statü, eğitim seviyesi ve daha pek çok etkenden dolayı türdeş değildir ve farklı statülerde ekonominin içinde yer alırlar. Bunlar bazen genel ekonomik bazense sektörel düzeyde bir takım ekonomik göstergeleri şekillendirebilir. Ancak kabul edilen ülke ekonomisine etkilerinin ölçülmesi ya da net bir şekilde ortaya konması, 
göçmenlerin arka planını da kapsayan pek çok örüntünün birlikte incelenmesiyle mümkün olacaktır. Bu değerlendirmede göç alan ülkenin mevcut ekonomik koşulları ve işgücü ihtiyacı da dikkate alınacak bileşenlerden biridir. İlgili alanyazına ilişkin bilgi paylaşımından önce Suriyeli mülteci göçünün genel özelliklerini ele almak konuyu daha anlaşılır kilacaktır.

Göç İdaresi Genel Müdürlüğü’nün 12 Mart 2020 tarihi itibariyle güncellediği verilere göre Türkiye'de geçici koruma altında kayıtlı olan Suriyelilerin sayıs1 3.588.131'dir. Geçici barınma merkezlerinde kalanların sayısı sadece 63.995 olarak kaydedilmiştir. Bunun dışında kalan 3.524.136 Suriyeli Türkiye'nin farklı şehirlerinde ve barınma merkezlerinin dışında yaşamaktadır. Yani Türkiye'deki geçici koruma altındaki Suriyelilerin yüzde 98,2'si mülteci kampları dışında kentsel alanlarda yaşamaktadırlar. Dünyanın genelinde kentsel alanlarda yaşayan mültecilerin oranı ise yüzde 60’tır (UNHCR, 2017, s.55). Bu nüfusun 2.097.264'ü 15-64 yaş aralığında olup, çalışma çağındaki nüfusu göstermektedir. Bu gruptaki kadınların sayısı 935.990'dır. İşü̈cüne katılma oranı erkeklerde \% 72, kadınlarda \% 32,5, istihdam oran1 ise erkeklerde \% 64,8, kadınlarda \% 26.7 olarak tahmin edilmektedir (Erdoğdu, 2018, s.26). Bu oranlar çerçevesinde kabaca ve genel bir hesaplamayla istihdamda bulunan Suriyeli mülteci sayısının kadınlarda 249.909, erkeklerde 752.505 olmak üzere toplamda 1.002.414 civarında olduğunu tahmin edebiliriz. Aile, Çalışma ve Sosyal Hizmetler Bakanlığ 1 Uluslararası İşgücü Genel Müdürlüğü tarafından yayınlanan Yabancıların Çalışma İzinleri 2018 adlı rapora göre 2018 yılı itibariyle neredeyse tamamı süreli olmak üzere çalışma izni verilen 115.837 yabancı uyruklunun yalnızca 34.573'ü Suriyelidir. 2018 yılına göre çok daha düşük sayılarda olduğu bilinen geçmiş yıllara ait çalışma izinlerini de eklediğimizde 900.000 sayısını rahatlıkla aşan sayıda Suriyelinin işgücü piyasasında kayıtdışı olarak yer aldığını tahmin edebiliriz. Bu sayıya özellikle tarımda çalışan 15 yaş altı çocuk işçiler de dahil edildiğinde daha da yükselmesi beklenir. Bu noktada Suriyeli mültecilerin işgücü piyasasında yer almasını düzenleyen yasal çerçeveyi incelemek gerekiyor.

Geçici koruma altındaki Suriyelilerin çalışma izinleri, Ocak 2016'da yürürlüğe giren Geçici Koruma Altındaki Yabancıların Çalışma İzinlerine Dair Yönetmelik ile ayrıntılı düzenlenmiştir. Buna göre geçici koruma sağlanan yabancılar, çalışma izni olmaksızın Türkiye'de çalışamaz veya çalıştırılamaz (madde 4). İzin alacak geçici koruma statüsündeki yabancılar ise, bağımsız çalışma iznine başvurma hakkı olanlar kendi adına, işverene bağlı çalışacak olanlarsa çalışacakları kurum üzerinden Çalışma 
Bakanlığı'na izin başvurusu yaparlar (madde 5). Mevsimlik tarım veya hayvancılık işlerinde çalışacak geçici koruma kapsamındaki yabancılar çalışma izninden muaftır. Bu kapsamdaki çalışma izni muafiyeti başvuruları, geçici koruma sağlanan il valiliğine yapılır ve valilik tarafından Bakanlığa bildirilir (madde 5, 4. fikra). Ancak geçici koruma statüsündekiler sadece ikamet izni verilen șehirlerde çalıșabilirler (madde 7). Calıșma izni başvurularının değerlendirilmesinde ise işyerinde çalışan Türk vatandaşı sayısı üzerinden sektör ve illere göre açık iş ve işe yerleştirmeler dikkate alınarak Bakanlıkça Türk vatandaşı sayısının yüzde onunu geçemeyecek şekilde değişen oranlarda istihdam kotası uygulanır (madde 8).

Yasal düzenlemeler geçici koruma statüsündeki Suriyelilerin formel biçimde işgücü piyasasında yer almasına olanak tanımasına karşın, halen çalışma izinlerinin çok düşük düzeyde kaldığı görülmektedir. Elbette ki kayıtdış1lığ1 tetikleyen pek çok etkenin varlığından söz edilebilir. İşgücü piyasasının yapısal sorunlarının yanında yasal düzenlemelere bağlı bileşenlerin kayıtdışılığ arttıran unsurlar olarak sayılabileceğini ifade etmeliyiz. Öncelikle söz konusu göçmen grubu için çalışma izni düzenlemesinin geç yürürlüğe girmesi kayıtdıșı çalıșmanın zeminini hazırlamıștır. Yasal düzenlemeye göre çalıșma izni başvurusunun, çalıșan değil de işveren tarafindan yapılması da engelleyici bir unsur olmaktadır. Öte yandan hareket klsitlılığ unsurlar olarak sayılabilir (Sunata, 2018, 183).

Tam da bu noktada işgücü piyasasının düzenleyici aktörleri olarak kabul edilen sosyal tarafların ve temsilcilerinin rolü büyük öneme sahiptir. İşçi örgütlerine yüklenen misyon gereği beklenen "hak temelli bir yaklaşım", yerli/yabancı ayrımı gözetmeksizin emeğin hak ihlallerine ve sömürü düzenine karşı korunmasını gerekli kılar. Kuşkusuz sendikal çabanın yanı sıra, politika yapıcıların işbirliğine açık tutumları da sendikal hareketin etkinliğinde belirleyici olmaktadır. Ancak ilgili alanyazında var olan çok sınırlı sayıdaki çalıșma, söz konusu tarafların temasının ve dolayısıyla işbirliğinin çok sınırlı düzeylerde kaldığını ortaya koymaktadır (Gökbayrak ve Erdoğdu, 2010; Erdoğdu, 2018; Cengiz, 2013). Suriyeli kitlesel göç akını öncesinde sendikaların düzensiz göçmen işgücüne bakışına yönelik yürüttükleri çalışmada Gökbayrak ve Erdoğdu (2010), sendikacıların göçmen işçilere karşı negatif bir tutum içerisinde olmadıklarını ancak göçmenlere karşı spesifik bir strateji geliştirmeyip konuyu enformel istihdam kapsamında değerlendirdiklerini ve enformel istihdam sorununu çözmede ise öncelikli aktör olarak devleti tanımladıklarını bulgulamışlardır. Erdoğdu'nun (2018, s.62), geçici koruma altındaki Suriyeliler özelinde yürüttüğü çalışma 
ise, geçici koruma altındaki Suriyelilere ilişkin olarak sendikal düzeydeki tepkilerde insani mülahazaların ikinci planda kaldığını, Suriyelilerin işgücü piyasası üzerindeki olumsuz etkilerinin ön plana çıktı̆̆ını ortaya koymuştur. Yine Erdoğdu sendikaların, bu olumsuz etkilerin giderilmesi için Suriyelilerin kayıtlı çalışmalarının sağlanmasını ve ucuz işgücü olarak yerel işgücü ile rekabete sokulmamasını savunduklarını belirtmesine karşın, Suriyelerle kurumsal temaslarının çok düşük olduğunu vurgulamaktadır.

\section{SURIYYLII MÜLTECILERIN UYUMU}

Türkiye'deki sayıları her geçen gün artan Suriyelilerin, süreç içerisinde ülkede kalma eğiliminin sürekli arttığı ve Suriye'deki iç savaş sona erse dahi önemli bir kısmının ülkelerine dönmeyeceği tahmin edilmektedir (Sirkeci, 2017; Kutlu, 2015; Orhan ve Şenyücel, 2015; Güçtürk, 2014). Buna karşı çeşitli kentlerde göçmenlere yönelik artan tepkiler, Suriyelilerin artık istenmediği, toplumsal kabul ve uyum sürecinin istenen düzeyde gerçekleşemediği yönünde bir eğilimin yaşandığını göstermektedir (Yıldırımalp, İslamoğlu ve İyem, 2017, s.107).

Uyuma ilişkin yapılan araştırmalar ise, uyum sürecinin etkileşimli doğası gereği, ekonomik, sosyo-kültürel, dilsel pek çok sorun alanına işaret ederek devletin ve yereldeki aktörlerin bir arada koordinasyon içinde çalışmasının gerekliliğine vurgu yapmaktadır. Uyum politikalarının tek elden (merkezi yönetim) yürütülmesi yerine yerel yönetimlere daha fazla inisiyatif verilmesi ve sivil toplum kuruluşlarının da sürece dahil edilmesi gerektiği konusunda ortak bir mutabakata varılmasına karşın merkezi yönetimin genel politikayı oluşturması asıl uygulamanın ise yerel düzeyde yapılmasının daha etkin olacağına vurgu yapılmaktadır (Taştan, İrdem ve Özkaya, 2018, 33-34). Salt yerel yönetimlere gönderme yapan, daha çok kültürel uyumun sağlanması çabasına işaret eden bu vurgu, göçmenlerin işgücü piyasasındaki durumlarını ve işçi örgütlerinin olası etkinliğini göz ardı eden bir yaklaşımı çağrıştırmaktadır.

Çalışma yaşamını merkeze koymayan bir uyum politikasının istenen sonucu vermeyeceği çok açıktır. Uyum sürecinde önemli olan pek çok alan, göçmenlerin sosyo-ekonomik durumlarıyla ilgilidir ve gerekli önlem alınmadığında diğer alanlarla olan etkileşim yeterli düzeyde sağlanamayacaktır. Örneğin, uyum sürecinin en önemli alanlarından biri kabul edilen eğitim, Suriyeli ailelerin ekonomik koşullarının kötü olmasına bağlı olarak çocukların okula gitmek yerine para kazanmak için çalışmak zorunda olmaları sonucunu doğurduğundan ciddi bir sorun alanıdır. Gelirin düşüklügü ve süreklilik teşkil etmemesi çocukları zorunlu olarak çalışmaya 
yöneltmektedir (Taştan, İrdem ve Özkaya, 2018, 35).

Çok yüksek sayılarda kayıtdışı çalışan nüfus barındıran söz konusu göçmen grubu, çalıştıkları süre zarfında iş kazası geçirdiklerinde ya da meslek hastalığına yakalandıklarında herhangi bir hak talep edemeyeceği gibi daha muhtemel ve yaygın görüldüğü şekliyle ücretleri ödenmediğinde de yasal olarak işverene yaptırım uygulanması yoluyla haklarını elde edemeyecektir. Suriyeliler için, işgücü piyasasında insan onuruna yakışmayan koşullarda konumlanmaları dolayısıyla Türkiye, bir kaçış noktası değil bir mücadele alanıdır (Dedeoğlu, 2016, s.54). Böylesine güvencesiz bir ortamda yalnızlaştırılan Suriyeli işgücü için uyum sürecinin pozitif yönde seyretmesini beklemek boş bir umuttan öteye geçemeyecektir. Diğer her şey olumlu iken dahi zorla yerinden edilenlerin, psikolojik olarak yaşadıkları travma dolayısıyla, göç ettikleri toplumla daha zayıf bağ kurmaları beklenen, olasılığı yüksek bir sonuçtur. $\mathrm{Bu}$ noktada insani perspektiften, hak temelli bir yaklaşım temelinde işçi ve işveren örgütlerinin geçici koruma altındaki Suriyeliler için insana yakışır işleri desteklemeleri, insan haklarını temel alan dayanışmacı ve içerici politikalar geliştirmeleri, aynı zamanda da bu politikaları farklı örgütlenme düzeylerine ve hepsinden önemlisi tabandaki üyelere ulaştırmaları büyük önem arz etmektedir (Erdoğdu, 2018, s.16)

\section{SURIYYLI MÜLTECILERIN UYUM SÜRECINDE İŞÇI ÖRGÜTLERININ AKTÖRLEŞ(EME)ME DENEYIMLERİ: BULGU ANALIZI}

Suriyeli mültecilerin uyumuna ilişkin yürütülen akademik çalışmalarda devletin ve yereldeki aktörlerin bir arada koordinasyon içinde çalışmasının gerekliliğine vurgu yapılmakla birlikte, pratikte çok da karşılık bulamadığı rahatlıkla ifade edilebilir. Ancak politika yapım süreçlerine doğrudan katılımı olmaksızın da işçi örgütleri kendi mücadele alanları içerisinde söz konusu olgu açısından görünürlük kazanabilirler. Kaldı ki işçi örgütleri açısından bu durum deneyimlenmemiş bir olgu değildir. Türk endüstri ilişkiler sistemi içerisinde görece zayıf çok yönlü diyalog mekanizmasını, yerel işgücü açısından öteden beri deneyimlediklerini söyleyebiliriz. Nasıl ki, varoluş gayesine uygun biçimde yerel işgücü açısından bu mücadeleyi sürdürme konusunda bir şekilde eylemlilik halini sürdürme çabası içindelerse, göçmen emeği konusunda da beklenen, işgücü ayrımı gözetmeksizin bu çabanın görünür kılınmasıdır. Tam da bu noktada, gerek göçmen emeğine yönelik yaklaşım farklılıkları gerekse eylemsizlik halinin nedenleri sırasıyla aşağıda incelenecektir. 


\subsection{Göçmen Emeğine Bakışta Söylem Düzeyinde Farklııklar: "Yerelci", "Hak Temelli", "İnsan Odaklı" Yaklașımlar}

Türk-İş, göçmenlerin işgücü piyasasına uyumunu sağlamak için bir çaba ortaya koymanın zorunluluğuna işaret etmekle birlikte, bu denli bir nüfusu işgücü piyasasına dahil etmeye çalışmanın, ulusal düzeyde bugüne değin elde edilmiş kazanımların ortadan kalkmasına neden olacağına vurgu yapmaktadır. "Yerelci" bir yaklaşım olarak ifade edebileceğimiz bu bakış açısı, uluslararası hukuk belgelerinde göçmenlere tanınan hakların yanında çok temel insan haklarından sayılan yaşama ve çalışma hakkının yok sayılması anlamına gelmektedir.

"Göçmen emeğine herhangi bir karşıtllk söz konusu değil. Göçmenleri bir şekilde entegre etmek zorundayız ancak her ülkenin, her ekonominin belli bir sinırı var. Biz bu sınırı hiç dikkate almadan tarihte görülmemiş bir sayıda göçmeni ülkemize kabul ettik. 70-80 yıldır tırnaklarımız ile kurduğumuz, eleştirsek de beğenmediğimiz noktalar olsa da bizim düzenli bir işgücü piyasamız var, işçi tarafimız, işveren tarafimız, kötü olsa da bir sosyal diyalog mekanizmamiz, istatistik kurumumuz yani bir yere getirdiğimiz işgücü piyasamı var. Bu kadar yoğun bir göçmen nüfusun girmesi demek bu kazanımlarımızl ortadan kaldırmak anlamina gelir. Belli bir limit olmasi gerekiyor. Bütün bu 4 milyonu kaldırabilecek kapasiteye sahip değiliz, bizim işgücü piyasamı buna uygun değil" (Türk-Işs).

DİSK, diğer tüm dezavantaj yaratan bileşenleri yok sayarak salt işgücü piyasasındaki yerli-yabancı işgücünün maruz kaldığ koşullar üzerinden olguyu ele alarak, sigortasız ve düşük ücretli çalışmanın göçmenlere has bir durum olmadığını, yerel işgücünün de aynı risklerle karşı karşıya olduğunu vurgulamakta ve böylelikle dilsel, kültürel, toplumsal, psikolojik pek çok faktörün göçmenler üzerinde yarattığ gölgelemektedir. Bu bakış, "hak temelli" bir yaklaşımı merkeze yerleştiren bir söylem algısı yaratsa da yerli ve yabancı işgücünün mevcut koşullarındaki farklılıkları göz ardı ederek meseleyi "işgücü hakkı" olarak genel perspektiften ele almak, göçmen emeğinin mağduriyetini görünmez kılmakta, özel gruplar için alınması gereken özel önlemleri perdelemektedir.

"Şöyle çok genel anlamda biz göçmen işçiler ve yerli işçiler gibi bir ayrım yapmiyoruz. Türkiye'deki işyerlerinde, fabrikalarda çalışan bütün iş̧̧iler bizim için tek bir kategori (...) Şimdi Suriyeli mülteciler söz konusu oluğunda işte sigortasız çalıştıkları 
için, düşük ücretlerle çalıştıkları için Türkiye'deki işgücü piyasasina olumsuz etkileri olduğu söyleniyor. Ama Türkiye'de, Türkiye vatandaşı işçiler de büyük çoğunlukla sigortasız, sendikasız ve çok düşük ücretlerle çalışıyorlar. Bu anlamda Suriyeli işçilerle Türk işçi arasında farklılık yok güvencesiz kötü çalışma koşulları açısından. Ücretleri düşüren genel anlamda işgücü piyasasını olumsuz etkileyen Suriyeli işçiler değil bize göre işveren ve patronlar" (DISSK).

Hak-İş, merkezinde insan olan bir yaklaşımları olduğunu yani meseleye insan odaklı yaklaştıklarını vurgulamakla birlikte, "elbette ki onlar da insan, insan gözüyle bakıyoruz", "kendi toplumumuz, kendi vatandaşlarımız" gibi söylemlerle göçmenleri algı düzeyinde öteki ya da ikincil derecede öneme sahip birey olarak konumlandırdığını açık etmektedir. Söylem ve alg1 düzeyinde kendini gösteren çelişki bir sonraki başlıkta yer verilen ifadelerinden açıkça anlaşılabilir.

"Hak-IŞ'in bütün faaliyetlerinin merkezinde insan var. İnsan ve onun emeği. Biz göçmenlere, mültecilere, siğınmactlara insan gözüyle baklyoruz. O ve onu, en kutsal değeri olarak insan şahsiyetini, kişiliği ve emeğiyle değerlendiriyoruz. Buradan varmak istediğim noktada şurası göçmenler, mülteciler ve siğınmacılar ĕger kendi vatanlarında insani yaşama koşullarında sahip olmuş olsalard y yani siyasi, dini anlamda ya da dünya görüşü anlaminda mutlu olsalardı zaten kendi ülkelerini terk etmezlerdi. Buna mecbur kaldıklarını düşünüyoruz ve böyle değerlendiriyoruz" (Hak-ISs).

\subsection{Tek Ortak Nokta: Söylem-Eylem Çelişkisi}

Devlet bir yandan Suriyeli göçmenlerin statüsünü geçici koruma olarak tanımlamayı sürdürürken bir yandan da uyum politikalarını tartışmayı başlatalı çok oldu. Bu kendi içinde bir çelişki gibi görünse de, söylemde ve yasal düzenlemelerde "misafirlik vurgusu" hâkimken, algıların bir yansıması olan eylemler, göçmenlerin kalıcılıklarının kabullenilmeye başlandığını göstermektedir. Kalıc1lıkları üzerine var olan algı ve bilinci yansitan eylemsel hareketlilik durumu, onların uyumlarının konuşuluyor olmasında kendini göstermektedir. İşçi örgütleri cephesinde de, bir söylem-eylem çelişkisinin söz konusu olduğu ifade edilebilir. İşçi örgütleri olarak konfederasyonların Suriyeli göçmenlere bakışında söylem farklılıkları olmasına karşın genel olarak olumlu yaklaşımların hakim olduğu, ancak eylem düzeyinde kendilerinin de ifadesiyle dikkate değer bir 
hareketliliklerinin olmadığ görülmektedir. Dolayısıyla Suriyeli mülteciler için işçi örgütleri açısından sadece "söylemsel kabul" ya da "sınırlı kabul"den söz edebiliriz. Uyum sürecine aktif bir katılım söz konusu değildir. İşgücü açısından "yabancı karşısında yerel, yerel karşısında işveren" üstünlüğünü pekiştiren bir eylemsizlik halinin hakim olduğu ifade edilebilir.

Türkiye için ani oldu birden bire oldu, hazırlıksız yakalandlk. Bu anlamda Avrupall sendikalarin deneyimlerini anlamaya çalışıyoruz (...) DISK'in göçmen emeği çalışma koşulları üzerine yapmiş olduğu faaliyetler yeterli düzeyde değil bunu kabul etmemiz gerekiyor. Türkiye'de ki işçiler de sendikasız çalışıyor. Sendikaların üye sayısı, kaynakları, gücü sinırlı. Disk de gücü ölçüsünde yapmaya çalışıyor ama bu bir takım imkânsızlıklardan dolayı göçmenlerle ilgili, mültecilerle ilgili yaptığımız çalışmalar sinırl. Daha çok ILLO üzerinden bu konuyu takip ediyoruz (...) Bu durum Türkiye'nin bir gerçeği ama maalesef biz dahil sendikalar henüz bu gerçeği kavramış, faaliyetlerini ona göre düzenlemiş durumda değil" (DiSK).

Göçmenleri öteki olarak algısında konumlandıran ve pek çok söylemiyle bunu ortaya çıkaran Hak-İş’in, aynı zamanda yabancı işgücü karışında yerel işgücünün üstünlüğüne dair algısı da şu ifadelerde bulunabilir:

Kendi vatandaşına geçinebilecek ücret, insan onuruna yakışır bir iş sunamadĭg ekonomik ortamda nasll olur da Suriyelilere çalışma imkânı sunar? Böyle bir imkân sunulursa bunu topluma nasıl anlatır. Suriyelilerin çoğu iş yerinde yatıp kalklyor, kayltdışı çalışıyor, ücretleri belki asgari ücretin 1/3'ü, günlük 3040-50 liraya çalıştığını duyuyoruz. Bu koşullarda iş arayan Türk vatandaşı haklı olarak serzeniş̧te bulunabiliyor yani eleştiri getirebiliyor. Hani ben senin ülkenin vatandaşlysam beni önceliklendirmen gerekmez mi ya da ona sunacağın firsatı bana sunsan? Dolaylsiyla Suriyelilerin istihdam talebine yönelik verilebilecek olası yanttların yol açabileceği toplumsal gerginlikleri gözümüzün önünde bulundurmamız lazım.

Başlangıçta meseleye "insan olmak" üzerinden yaklaştı̆̆ını ifade eden Hak-İş, görüşmenin ilerleyen kısımlarında yerel işgücüne yönelik sorumluluklarını öne çıkararak, onların serzenişlerini "haklı" kılacak asayiş sorunlarından örneklerle "kendi vatandaşı"nın rahatsızlığına vurgu 
yapmaktadır.

Zaman zaman ufak tefek asayiş olaylarını görüyor, kavgaları gürültüleri duyuyoruz. Suriyeli kaynakl işgücü piyasasında, soysal hayatta yaşanan sorunlar maalesef kendi toplumumuzda kendi vatandaşlarımızı rahatsı edebiliyor. Elbette ki onlar da insan, insan gözüyle baklyoruz ama kendi ülkemiz kendi toplumsal değerlerimiz konusunda baktı̆̆ımız zaman da... Suriyelilerin ülkemize keyfi keder olarak gelmediklerini onların en temel ihtiyaçlarınin can güvenlikleri ve onlar hayata bağlayan asgari koşullar olduklarını topluma anlatmak gerekiyor. Bir takım kamu spotları görüyoruz hatta Hak-Iş olarak da benzer çalışmaları yaptık ama kapsamları ve yetkileri çok sinırlıdır" (Hak-ISs).

\subsection{Deneyimlere Yansıyan Algı: Suriyeli Mülteci Emeğine Yönelik Mücadelede İşçi Örgütlerinin İkilemi}

Araştırma kapsamında işçi örgütlerinin, Suriyeli mültecilerin kalıcılıklarından emin olmadan yerel işgücünü karşısına almak istemediğine ilişkin genel bir gözlemimiz oluşmuştur. Aslında hepsinde farklılaşan gerekçeler, bir eylemsizlik ve mücadeleden uzaklaşma durumunu beraberinde getirmektedir. Sonuç itibariyle iş̧̧i örgütleri, sendikal mücadelenin bu süreçte varlık kazanması ve doğası gereği mücadele etmesi gerektiğine işaret etmelerine ve inanmalarına karşın, kimi yerel işgücünün tepkisini haklı bularak ya da tepkisinden çekinerek kimi de öğrenilmiş çaresizliğin bir yansıması olan söylemlerle sürecin içinde yer alma ikilemi yaşadıklarını ifadeleriyle yansıtmışlardır.

"Bunları bilirken ve görürken sendikalar ne yapıyor?(...) Aslında işaret edilse bile müdahale edilmediği bir dönemden geçiyoruz. Yoksa herkes İstanbul Çağlayan'da tekstilde kayıtdışı çalışan işçileri biliyor.(...) Aslında bu bize şunu gösteriyor; sistem içerisinde şu anda buna müdahale edilebilecek durum söz konusu değil. Şuanda bizim sendikalı işçimizin hak kaybı söz konusu değil, çünkü sendikalı olan işyerlerine Suriyeliler giremiyor. Çünkü burasl görece daha iyi is yerleri oluyor. Ama Suriyelilerin kayıtdışında yer alması ve Suriyelilerle ilgili adım atılmaması, bundan 5 yll sonra sizin sendikal haklarinizl da inceltmeye ve ortadan kaldırmaya başlayacak. Ücretler baskılanırsa eğer $\mathrm{ki}$ güvencesiz çalışma bu şekilde bu yönde artmaya devam ederse sendikal haklarınız bir şekilde esnetilecektir. Zaten keza 
esnetiliyor. Sendikalar ancak devlet mekanizmasina durumu ifade ederler ve devletin bu konuda göreve gitmesi için baskl yaparlar. Baskl nasıl yapllır bu biliniyor ama bu dönemde artık o tür baskıların olmadığını biliyoruz. Yani her şeyin şekil değişsirdiği bir süreçten geçiyoruz. Aslında sendikaların gücü sokaktır. Sendikal eylemleri bu şekilde yaparlar. Hep birlikte biliyoruz ki grevlerin bakanlar kurulunca iptal edildiği süreçten geçtik. Bunların hepsi gü̧ kaybettirdi" (Türk- $\dot{I}_{\text {Ş}}$ ).

Görüşme süresince birden çok kez, bu süreçte de (Suriyeli mültecilerin uyum sürecinde) her zaman ki gibi yine dikkate alınmadıklarına gönderme yapan DİSK ise ancak empati yoluyla yerel işgücünün göçmenlere bakışını değiştirmeye çalıştıklarını vurgulamakla birlikte, sendikaların gücünün bu süreci olumlu etkilemeye yetmeyeceğine işaret etmektedir:

"Işste bizim kendi sorunlarımı varken Suriyelilerle mi ilgilenilecek gibi tepkiler geliyor. Ben hemen bu soruya cevabım “memleket neresi, siz nerelisiniz” oluyor. Türkiye nüfusunun Türkiye'de işçilerin çalı̧̧anların büyük bir bölümü ya kendileri ya da bir kuşak önce zaten Türkiye'nin dışından gelmiş insanlar. Dolayıstyla önce bir empati kurmalarını sağlamaya çalışıyoruz. Bizim örgütlü olduğumuz işyerinde herhangi bir stkintı yaşanmiyor ama çevredeki fabrikalarda veya mahallelerde bu tür gerilimler yaşanıyor. $O$ zaman biz üyelerimizle birlikte irtibatta olduğumuz üye olmayan işçilerle görüşmeler yapıyoruz. Empati kurmalarını sağllyoruz. Beraber çalışlyoruz, beraber yaşıyoruz bu ülkede. Sorunlarımızı da beraber çözmemiz gerekiyor, bunu vurguluyoruz sürekli (...) Zaten sendikalar yeterince güçlü olmadıkları için yaptıkları faaliyetler çoğu zaman etkili olmuyor. Türkiye'de ki sendikalaşma oranı \%10'dan az, toplu sözleşme kapsaminda olanlar daha da az. Sosyal diyalog mekanizmalar da etkili bir bicimde çalışmıyor. Dolaylsıyla düzenlemelere katılmamı istişarelere katılmamı da pek mümkün değil. Sendikaların bu konu da yaptığı eleştiriler çok dikkate alınmıyor. Genel anlamda bazı yayınlar çıkarıyoruz bazı açıklamalar yapıyoruz ama çok dikkate alındığını söylemek doğru olmaz” (DISK).

HAK-İ̧̧ ise daha çok Suriyelinin işgücü piyasasına çekilmesiyle gerginliğin daha belirgin bir hale gelme olasıllı̆ıına dikkat çekerek ve kendilerini sürecin etkili aktörleri olarak görmeyerek, daha üst düzeyde çözümler üretilebileceğini ifade ediyor. 
"Işste bu toplumsal gerginlik alanları maalesef var. Tahmin ediyorum daha çok Suriyeliyi işgücü piyasasına çekersek eğitim sektörüne çekersek belki bu gerginlik alanları daha belirgin bir hale gelir. Ümit ederiz ki bu sosyal itilaflar, sosyal uyuşmazlık alanları daha kolay bir şekilde daha üst bir seviyede etkili bir şekilde çözülebilir" (Hak-Iss).

\section{Kayıtdışılık}

6.4. Uyum Sürecinin Birincil Sorun Alanı: İstihdam ve

Esser'in (2000) entegrasyon kuramına gönderme yaparak yapısal faktörlerin daha çok öne çıktığını ve toplumsal yaşamın diğer alanlarına dahil olabilmek için temel koşulun iş piyasasında güvenli bir istihdam olduğunu ifade eden Kartal (2018, s.125) ile uyumlu görüş bildiren TÜRKİş uyum sürecinin $\% 75$ 'inin istihdam ve gelirle ilgili olduğunu ifade etmektedir:

"Uyum sürecinin en belirleyici etmenleri bir gelir kaynağına sahip olmalarıdır. Gelir kaynağına da iki şekilde sahip olabilirler. Ya Türkiye Cumhuriyeti bunlara kaynak sağlayacak, yardım edecektir ya da istihdamın içinde yer alacaklar para kazanacaklar. Birinci kaynak zaten olmayacağı için uyum sürecinde birinci koşul gelirlerini elde etmeleri ki bu çok önemli" (Türk-Iss).

Türk-İs, uyum sürecinde en ve birinci derecede önemli belirleyici etmenin gelir kaynağına sahip olmak olduğunu söyledikten sonra, ikinci sırada eğitim ve sağlık sorunlarının geldiğine dikkat çekmektedir. Bu sorun alanlarına değinirken de satır aralarında mültecilerin ülkeye olan maliyetlerinden ve yerel halkın doğal ve olağan kabul edilecek tepkilerinden söz etmektedir:

"İkincisi de eğitim ve sağllk bunlara da biraz değinmek istiyorum. Mesela ilçemiz 20.000 nüfuslu, ancak oranın bir hastane kapasitesi var idi. Birden Suriyeli nüfus gelince ve aynen tek hastane varken sayı iki katına çıktı, üç katına çıktı. Sağlıktan yararlanma koşullarl düşü, hizmet kalitesi düştü. Doktor ve hemşire sayısı aynı ancak nüfus üçe katlandl, bu bir sorun. Eğitimde ise okul sayını aynı, öğretmen sayını aynı ama ögrenci sayınız ikiye üçe katlandı, bunlar çok ciddi sorunlar aslinda ve uyum sürecinde bunlarn da bir yeri ve önemi var. Ayrıca uyum sürecinde toplumun tepkisi de çok önemli. Ankara Üniversitesi'nden açıklanmayan bir araştırma var, maliye 
tarafindan yapılan. Bir buçuk milyar yıllık sadece atık maliyeti bir büyükssehir belediyesine ait. Çok af edersiniz yiyorlar içiyorlar tabi ki bir atık söz konusu olacak. Belediyecilik masrafi dahi bir buçuk milyar hiçbir şey olmasa bile. Katkıları yok, vergi gibi herhangi bir katkısı yok bu nüfusun. Peki, bu bir buçuk milyar maliyeti devlet nerden karşılayacak? Çok belli nerden karşılayacağı, bizden vergi alacak ve karşılayacak. Doğal olarak bu vergiler kayltlı çalışanlara ayrıca bir ek maliyet olmaya başliyor. Aslında bunların hepsi birbiriyle bağlantıll. Doğal olarak da cebindeki para biraz daha azalan vatandaş buna göre bir tepki öne çıkartıyor. Uyum sürecinde aslında bunların da çok önemli olduğunu düşünüyorum. Ama bunların en yukarısında istihdam var, sonrasinda eğitim ve să̆llk" (Türk-Işs).

DİSK de benzer görüşü paylaşarak uyum sürecinin olumsuz seyretmesinde ve yaşanan gerginliklerin temelinde istihdam ve çalışma ile ilgili konuların yer aldığını ifade etmektedir. Ancak dezavantajlı grupların kendi içerisinde hissettikleri çatışma algılarının düzeyindeki farklılaşmayı göz ardı eden bir bakışın uzantısı olarak yerel-yabancı ayrımı gözetmeksizin sorunun ele alınmasına vurgu yapmaktadır. Çalışmanın kuramsal bölümünde ifade edildiği üzere, göçmenlerin özellikle mülteciler, sığınmacılar ya da belirsiz statüde olanların göç sonrası süreçte hissettikleri çatışma ve güvensizlik algılarının yüksek olması muhtemeldir. Dolayısıyla yerel işgücünün yaşadığı benzer sorunlara maruz kalan göçmen için güvensizlik algıs1 çok daha yüksek olabilir. $\mathrm{Bu}$ bakış, birinin diğerine üstünlüğünü savunan bir görüşün yansıması olarak değil, tersten bir okumayla, birinin diğerine göre görece hassasiyetini öne çıkaran bir anlayışın uzantısı kabul edilmelidir.

“Ama Türkiye'de zaten herkes, sadece Suriyeliler değil, Türkiyeliler de sigortasız bir şekilde kötü koşullarda düşük ücretlerle gelecek kaygısı içinde çalışıyor. Dolayısıyla ayırt etmemek lazım. Türkiye'de çalışan bütün işçiler için kayıtlı sigortalı güvenceli insan onuruna yakışır bir iş için mücadele etmek gerekiyor" (DISK).

Kaldı ki eşitlikçi bir bakışın ifadesi olan bu söylemler, pratikte ya da eylemde karşılık görmediği sürece "kabulün" sınırlı versiyonuna işaret eder. Öyle ki araştırma sürecinde görüşmeler dışında belge, doküman ve ilgili kuruluşun yayınları vs. üzerine yaptığımız incelemelerde, göçmen ve özelde Suriyeli mülteciler üzerine yapılan araştırmaların diğer konfederasyonlarda olduğu gibi DİSK'te de çok sınırlı olduğu görülmüştür. 


\section{5. İşçi Örgütlerinin Aktörleş(eme)me Deneyimleri}

Görüşülen üç konfederasyon da Suriyeli mültecilerin uyumu sürecinde devleti temel aktör olarak görmelerine karşın işçi örgütlerini de sürecin belirleyici, etkin aktörleri olarak tanımlamışlardır. Uyum sürecinde proje desteğiyle görece daha etkin rol almaya dönük çaba ortaya koyan Hakİş, yine proje temelli sağlayabilecekleri destekleri şöyle aktarmıştır:

"Toplantılarda ya da oturumlarin bazılarinda elbette $k i$ tespitleriniz, önerileriniz neler, neler yapılabilir diye sorulduğunda ya da söz verildiğinde biz önerimizi ortaya koyuyoruz. Ama her önerinin hayata geçirilmesi için bir takım asgari koşullar var, hedef kitle, zaman, mekan, finansman desteği gibi. Böyle olunca da sunduğumuz her önerimiz için somut bir imkan ya da ortam bulamiyoruz. (...) Somut bir örnek olması açısından 2015 yılında Erasmus Plus projesi kapsamında sunduğumuz mesleki eğitim yoluyla mültecilerin sosyal entegrasyon projesini 2015-2016-2017 yılında yaklaşık 2 yll aşkın bir süre uyguladık. Ancak proje bitince, proje kapsamında uyguladı̆̆ımız dil eğitimi, bulaşıkhane ve çamaşırhane mesleklerine ilişkin kurslar da maalesef sona erdi. Konfederasyon olarak elbette $k i$ bizim de finansman kaynaklarımı, idari kapasitemiz var ama sinırlı. Sinırsiz bir imkana sahip olduğumuzu söyleyemeyiz. Böyle olunca da kafamızdaki ya da yapmak istediğimiz her projeyi hayata geçiremiyoruz" (Hak- $\left.\dot{I}_{\text {S }}\right)$.

Ancak buraya kadar elde edilen ve paylaştı̆̆ımız bulgular, işçi örgütlerinin sürecinin etkin bir tarafi olamadığını ve dolayısıyla aktörleşemediğini ortaya koymaktadır. Elbette ki burada farklı düzeylerde tetikleyici olan pek çok unsur sıralanabilir: Birincisi, yerel işgücünün tepkisinden kaçınma durumu aktörleşme deneyimlerini şekillendirmektedir ki yukarıda görüşmeci söylemleriyle açıkça ortaya konmuştur. İkincisi, Suriyeli mültecilere yönelik var olan "misafir" algısı belirleyici bir diğer etkendir.

"Maalesef biz bu göç hareketini en başından doğru yönetemedik. Sandık ki biz bunları alacağız bir iki yll barınırlar, Suriye'de koşullar düzelir ve ülkelerine geri dönerler. Yani geçici misafir gözüyle baktık hatta adı da geçici koruma altındaki Suriyeliler olarak lanse ediliyor. Mülteci demeye bile çekiniyoruz. Bu gö̧ hareketini başından beri doğru yönetebilseydik, bugün ortaya 
çıkan sorunları 2012 yllında, 6-7 yıl önce, öngörebilseydik tahmin ediyorum bugün konuştuğumuz sorunların bir kısmı ortaya çıkmamış olacaktı. Ülke olarak hükümet olarak çok daha belirgin bir strateji ortaya koyarak bir şekilde bu Suriyeleri ülkemizde misafir etseydik_ve altından kalkabileceğimiz kadarın ağırlasaydık gibi bir kanaat ortaya çıkmıyor değill” (Hak-İ̧).

İşçi örgütlerinin uyum sürecinin etkin ve belirleyici bir tarafi olamamasının üçüncü nedeni, sürecin bir parçası ve etkin bir mekanizması olarak kabul edilmemeleridir..

"Bize uyum sürecinde misyon ve vizyon çizdirilebilir. Birincisi bu kitlenin ihtiyaçlarının doğru anlaşılması konusunda bazı anketleri biz yapıp kamuoyuyla paylaşabiliriz (...) Biz Hak-Işs olarak proje kültürünü benimsemiş bir konfederasyonuz, emek örgütüyüz. Biz bu hedef kitlenin ihtiyaçlarına yönelik bir takım sosyal projeleri, mesleki eğitim projelerini uygulayabiliriz. Bu kitlenin Türkiye'deki kültürel, sosyal hayata ve iş gücü piyasasına nasil entegre olacaklarina dair bilgilendirme faaliyetleri gerçekleştirebiliriz, biz bunları yapabiliriz" (Hak-Işs).

Öncelikle ifade etmemiz gerekir ki, YUKK kapsamında da düzenleme bulan uyum politikasına ilişkin girişimler, pratikte henüz tam anlamıyla karşılık bulmamıştır. YUKK'un uyum başlıklı 96. maddesine göre;

"Genel Müdürlük, ülkenin ekonomik ve mali imkânları ölçüsünde, yabancı ile başvuru sahibinin veya uluslararası koruma statüsü sahibi kişilerin ülkemizde toplumla olan karşılıklı uyumlarını kolaylaştırmak ve ülkemizde, yeniden yerleştirildikleri ülkede veya geri döndüklerinde ülkelerinde sosyal hayatın tüm alanlarında ü̧̈üncü kişilerin aracılığı olmadan bağımsız hareket edebilmelerini kolaylaştıracak bilgi ve beceriler kazandırmak amacıyla, kamu kurum ve kuruluşları, yerel yönetimler, sivil toplum kuruluşları, üniversiteler ile uluslararası kuruluşların öneri ve katklarindan da faydalanarak uyum faaliyetleri planlayabilir". Yine aynı maddenin 3. fikrasina göre, "kamusal ve özel mal ve hizmetlerden yararlanma, eğitime ve ekonomik faaliyetlere erişim, sosyal ve kültürel iletişim, temel sağllk hizmeti alma gibi konularda kurslar, uzaktan eğitim ve benzeri sistemlerle tanitım ve bilgilendirme etkinlikleri Genel Müdürlükçe kamu kurum ve kuruluşları ile sivil toplum 
kuruluşlarıyla da iş birliği yapılarak yaygınlaştırılır”.

Ancak konfederasyonlarla gerçekleştirilen görüşmeler, işçci örgütlerinin uyum politikalarına ilişkin düzenlenen toplantılara kısmen dahil edildiklerini ortaya koymaktadır.

"Esas aktör burada devlet olmalı. Uzun vadeli kalıcı bir program yapılmalı ancak ortada bir planlama yok. Yapılan toplantılarda özellikle Suriyeli işçilerin işçi temsilcilerinin olmadiğını görüyoruz. Türkiye işverenlerinin, Suriyeli işverenlerin temsilcileri ile uluslararası kuruluşların temsilcileri var ama Suriyeli işçilerin temsilcileri olmuyor masada. Dolayısıyla sahadan, tabandan görüşleri doğrudan alamıyoruz. Sadece araştırmacıların, akademisyenlerin raporlarını, gözlemlerini dinliyoruz. Bizim açımızdan, sendikalar açısından bu konuların planlanmasında Suriyeli işçilerin rol almaması, onlarında söz sahibi olmaması, fikirlerine başvurulmaması önemli bir eksiklik (...) Türkiye'de çalışma hayatı ile ilgili kararlarda sendikalara, işçilere sorma kültürü geleneği yok. Bu anayasal güvence altında olmasına rağmen uygulanmiyor. Suriyeli mültecilerin işgücüne entegrasyonu konuşulacaksa mevcut sendikaların işkolu veya konfederasyon düzeyinde masada söz hakkını olmasi gerekiyor ama bu konuda da hiçbir konuda olmadiğl gibi sendikalara söz hakkl, karar hakkl verilmiyor" (DISK).

Türk-İş ve Hak-İş, ilgili kamu otoriteleri tarafından organize edilen toplantılara çokça davet edildiklerini ve olabildiğince yer aldıklarını ifade ederken, DİSK herhangi bir toplantıya davet edilmediğini, ancak İLO kapsamında düzenlenen toplantılarda yer alarak bu yolla görüşlerini sunduklarını bildirmiştir.

\section{7. ÖZ VE SONUÇ YERINE}

İşçi örgütlerinin genelde göçmen, özelde Suriyeli mülteci emeğine yönelik yaklaşımları, söylem düzeyinde "yerelci", "hak temelli" ve "insan odaklı” olarak farklılaşmalarına karşın, pratikte “"“yabancı karşısında yerel işgücü üstünlüğünü pekiştiren bir eylemsizlik" olarak karş1lık bulmakta ve "söylem-eylem" çelişkisi üç iş̧̧i örgütünde de görülmektedir. Dolayısıyla Suriyeli mülteciler için, işçi örgütleri açısından sadece "söylemsel kabul" ya da "sınırlı kabul" den söz edebiliriz. Uyum sürecine aktif bir katılımın söz konusu olmadığı rahatlıkla ifade edilebilir.

İşçi örgütlerinin tümü, temel gelir kaynağına sahip olmayı uyum 
sürecinin birincil belirleyicisi olarak görmektedirler. Dolayısıyla onlara göre de, birincil sorun alanı istihdam ve kayıtdıș1lıtır. Ancak kendilerini sürecin olağan ve doğal aktörleri olarak görmelerine karşın, etkin bir rol alamadıkları ve aktörleşemedikleri çalışmanın temel bulgularından biridir. Burada üç nedenin belirgin olduğu gözlenmiştir: Birincisi, örgütlerin tabanındaki genel eğilimin dayanışmacı değil olumsuz ve dışlayıcı olması, sendikalarda bir çekince yaratarak uyum sürecindeki mücadeleci tutumlarını törpülemektedir. İkincisi, işçi örgütlerinin Suriyeli mültecilere yönelik "misafir" algısı sürecin etkin bir parçası olmalarının önündeki diğer bir engeldir. Üçüncüsü ise, politika yapıcılar düzeyinde sürecin etkin bir mekanizması olarak kabul edilmemeleridir. Dolayısıyla, işçi örgütlerinin Suriyeli mültecilere yönelik misafirlik algısı ve bunun üzerine stratejilerini kurgulamaları, politika yapıcıların kendilerini sürece dahil etmemeleri ve yerel işgücünün tepkisinden duydukları çekince, Suriyeli mültecilerin uyum sürecinde etkin bir şekilde aktörleşememelerinin temel nedenleri olarak siralanabilir.

İşçi örgütleri olarak konfederasyonların söz konusu bu fenomen ile ilgili yaşanmış deneyimlerinin ne anlama geldiğini tanımlamaya çalıştığımız bu çalışmada son olarak ifade etmeliyiz ki, siyasetin şekillendirdiğ söylemler, ekonomik yapı ya da yapısal ekonomik sorunlar, toplumsal tepkiler vb. etkenlerin, güzergahından şaşmış, yol ayrımlarında kaybolmuş bir sendikal tutumu ortaya çıkardığı görülmektedir.

\section{KAYNAKLAR}

Betts, A., Bloom, L., Kaplan, J., \& Omata, N. (2014). Refugee economies: Rethinking popular assumption. University of Oxford Refugee Studies Centre, 210-212.

Cengiz, B. (2013). Türkiye'de sendikaların düzensiz emek göçüne bakışı: İstanbul örneği. Yayınlanmamış Yükseklisans Tezi, Marmara Üniversitesi, İstanbul.

Cohen, J. H., \& Sirkeci, İ. (2011). Cultures of migration: The global nature of contemporary movement. USA: University of Texas Press.

Creswell, J. W. (2007). Qualitative inquiry \& Research design: Choosing among five approaches. Thousand Oaks: Sage Publications.

Dedeoğlu, S. (2016). Türkiye'de mevsimlik tarımsal üretimde yabancı göçmen iş̧̧iler mevcut durum raporu: Yoksulluk nöbetinden yoksulların rekabetine. Ankara: Kalkınma Atölyesi.

Dukes, S. (1984). Phenomenological methodology in the human sciences. Jurnal of Religion and Health. 23(3), ss. 197-203.

Erdoğdu, S. (2018). Syrian refugees in Turkey and trade union responses. Globalization, 15 (6), 838-853.

Erdoğdu, S. (2018). Türkiye'de geçici koruma altındaki Suriyeliler için insana 
yakışır işlerin desteklenmesi iş̧̧i ve işveren örgütleri ne yapmalı? Ankara: Uluslararası Çalışma Örgütü.

Esser, H. (2000). Integration and ethnic stratification. Freudenberg Stiftung informiert, 1, 49-84.

Finlay, L. (2009). Debating phenomenological research methods. Phenomenology \& Practice. 3 (1), 6-25. https://doi.org/10.29173/pandpr19818.

Göç İdaresi Genel Müdürlüğü, https://www.goc.gov.tr/gecici-koruma5638, 30.03.2020.

Gökbayrak, S., \& Erdoğdu, S. (2010). Irregular migration and trade union responses: The case of Turkey. "IŞ, GÜÇ" Endüstri Illişkileri ve Insan Kaynakları Dergisi, 12 (2), 89-114.

Güçtürk, Y. (2014). Sürgün ile savaş arasinda Suriyeli mülteciler. Ankara: Siyaset, Ekonomi ve Toplum Araştırmaları Vakfi (SETA).

Güler, A., M. B. Halıcıoğlu \& S. Taşğın. (2013). Sosyal bilimlerde nitel araştırma yöntemleri. Ankara: Seçkin Yayıncılık

Hein, S. F., \& Austin, W. J. (2001). Empirical and hermeneutic approaches to phenomenological research in psychology: A comparison. Psychological Methods, 6(1), 3-17.

Kartal, B. (2018). Sığınmacı statüsünün dönüşümü ve entegrasyon. B. Kartal ve U. Manço (Ed.). Beklenmeyen Misafirler, Suriyeli Siğınmacılar Penceresinden Türk Toplumunun Geleceği içinde (ss.13-29). İngiltere: Transnational Press London.

Khattab, N., Sirkeci, I., Johnston, R., \& Modood, T. (2011). Ethnicity, religion, residential segregation and life chances. T. Modood and J. Salt (Eds.) In Global Migration, Ethnicity and Britishness (pp.153-176). London: Palgrave, Macmillan,

Kockelmans, J. J. (1973). On Myth and its relations to hermeneutics. Cultural Hermeneutics 1, 47-86, Holland: Reidel Publishing Company.

Kutlu, Z. (2015 Ocak-Nisan), Bekleme odasindan oturma odasina: Suriyeli mültecilere yönelik çalı̧̧malar yürüten sivil toplum kuruluşlarına dair kisa bir değerlendirme, Anadolu Kültür \& Açık Toplum Vakfi.

Orhan, O., \& Gündoğar, Ş, S. (2015 Ocak), Suriyeli Siğınmacıların Türkiye'ye Etkileri, ORSAM \& TESEV Raporu, No 195, Ankara: ORSAM.

Oumarou, M., \& Tomei, M. (2017). Foreword. S. Marino, J. Roosblad \& R. Penninx (Eds.) in Trade unions adn migrant workers new contexts and challenges in Europe, USA: Edward Elgar Publishing \& Geneva, Switzerland: International Labour Office

Sirkeci, İ. (2009). Transnational mobility and conflict. Migration Letters, 6 (1), 3-14

Sirkeci, İ. (2012). Transnasyonel mobilite ve çatışma. Migration Letters. 9 (4), 353363.

Sirkeci, İ. \& Cohen, J. H. (2016). Cultures of migration and conflict in contemporary human mobility in Turkey. European Review, 24 (3), 381-396.

Sirkeci, İ. (2017), Bir güvensizlik ülkesi olarak Türkiye'nin mültecileri: Suriyeliler ve Türk mülteciler, Göç Dergisi, 4 (1), 21-40 
Sunata, U. (2018). Suriyeli sığınmacıların emek piyasasına katılımları. B. Kartal \& U. Manço (Ed.) Beklenmeyen Misafirler, Suriyeli Siğınmactlar Penceresinden Türk Toplumunun Geleceği içinde (ss. 169-196). İngiltere: Transnational Press London.

Taştan, C., İrdem, İ., \& Özkaya, Ö. (2018). Politika ve uygulama boyutlarıyla göç ve uyum. Ankara: GÖÇMER, Polis Akademisi Başkanlığı.

Tijdens, K. G., \& Klaveren, M. van. (2011). Over- and underqualifiction of migrant workers. Evidence from Wage Indicator survey data. AIAS Working Paper; No. 11-110. Amsterdam: University of Amsterdam.

Uluslararası İşgücü Genel Müdürlüğü. (2017). Çalışma hayatı istatistikleri, https://birim.ailevecalisma.gov.tr/media/11707/calısma-hayati-istatistikleri2017.pdf

UNHCR. (2017). Global trends, forced displacement in 2016, http://www.unhcr.org/ statistics/unhcrstats/5943e8a34/global-trends-forced-displacement2016.html

Unutulmaz, O. (2012). Gündemdeki kavram: "Göçmen entegrasyonu”, Avrupa'daki gelişimi ve Britanya örneği. S. Gülfer Ihlamur Öner \& N. Aslı Şirin Öner (Ed.) Küreselleşme Çağında Gö̧ Kavramlar, Tartışmalar içinde (ss.135161). İstanbul: İletişim Yayınları.:-

Yıldırımalp S., İslamoğlu E., \& İyem C. (2017). Suriyeli sığınmacıların toplumsal kabul ve uyum sürecine ilişkin bir araştırma, Bilgi, 35 Klş / Winter, 107-126 
